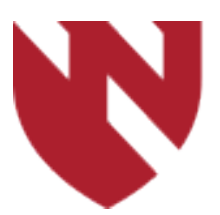

\title{
Personal Finance Skills Among Health Professionals: Piloting A Student-Led Finance Curriculum And A Review Of The Current Landscape
}

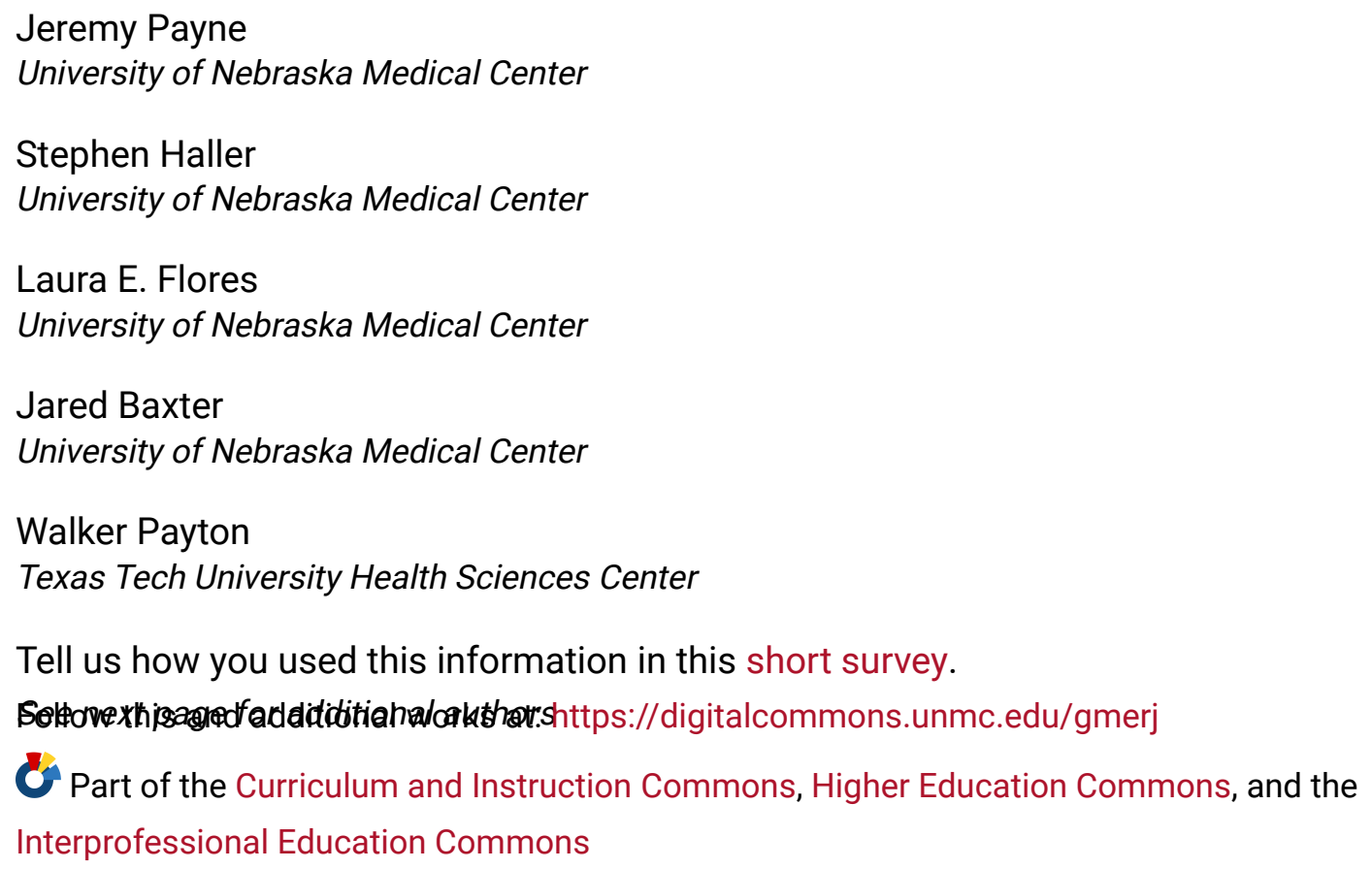

\section{Recommended Citation}

Payne, J., Haller, S., Flores, L. E., Baxter, J., Payton, W., , Nelson, K. Personal Finance Skills Among Health Professionals: Piloting A Student-Led Finance Curriculum And A Review Of The Current Landscape. Graduate Medical Education Research Journal. 2020 Dec 09; 2(2).

https://digitalcommons.unmc.edu/gmerj/vol2/iss2/3 


\title{
Personal Finance Skills Among Health Professionals: Piloting A Student-Led Finance Curriculum And A Review Of The Current Landscape
}

\begin{abstract}
Introduction

Despite high costs of education, extended lengths of training, and rapidly increasing student debt, personal finance is an often-overlooked topic within professional school curricula. Due to the combination of high debt burden and poor financial literacy, professional students report low confidence and high stress regarding their personal finances. While some medical schools have begun to integrate financial education into their formal training, others provide little to no resources to combat this growing issue.

\section{Methods}

To address this gap and provide financial education opportunities, the Financial Development Club (FDC) was founded by students at the University of Nebraska Medical Center. The FDC aimed to fill gaps in financial knowledge through four, one-hour seminars on topics identified by students as being particularly relevant. Following implementation of this seminar series, surveys assessing student attitudes towards the presented financial topics were distributed to all students on campus, and results were stratified by attendance and non-attendance at the seminars.
\end{abstract}

\section{Results}

Students who attended the seminars rated themselves as significantly more comfortable with all four financial topics (e.g. debt management, budgeting, investing, and retirement) compared to their peers who did not attend $(p<0.05)$.

\section{Conclusions}

These findings demonstrate the efficacy of a small scale, student-run initiative to increase financial literacy on a single campus. Not only are these results a promising indication of the utility of a single club, they also offer a scaffold on which to build a formal personal and health care finance curriculum.

\section{Keywords}

Personal finance, medical education, interprofessional education, debt management, financial planning, educational curriculum

\section{Creative Commons License}

\section{(c) $($ i) $(9)$}

This work is licensed under a Creative Commons Attribution-Noncommercial-No Derivative Works 4.0 License.

\section{Authors}

Jeremy Payne, Stephen Haller, Laura E. Flores, Jared Baxter, Walker Payton, and Kari Nelson 


\section{Personal Finance Skills Among Health Professionals: Piloting a Student-Led Finance Curriculum and a Review of the Current Landscape}

Jeremy Payne', Stephen J. Haller', Laura Flores' ${ }^{1}$, Jared Baxter², Walker Payton ${ }^{3}$, Kari Nelson ${ }^{4}$

${ }^{1}$ University of Nebraska Medical Center, College of Medicine, Omaha, NE

${ }^{2}$ University of Nebraska Medical Center, College of Medicine, Department of Emergency Medicine, Omaha, NE

${ }^{3}$ Texas Tech University Health Sciences Center, School of Medicine, Department of Pediatrics, Lubbock, TX

${ }^{4}$ University of Nebraska Medical Center, College of Medicine, Office of Graduate Medical Education, Omaha, NE

\section{Abstract}

Introduction: Despite high costs of education, extended lengths of training, and rapidly increasing student debt, personal finance is an often-overlooked topic within professional school curricula. Due to the combination of high debt burden and poor financial literacy, professional students report low confidence and high stress regarding their personal finances. While some medical schools have begun to integrate financial education into their formal training, others provide little to no resources to combat this growing issue.

Methods: To address this gap and provide financial education opportunities, the Financial Development Club (FDC) was founded by students at the University of Nebraska Medical Center. The FDC aimed to fill gaps in financial knowledge through four, one-hour seminars on topics identified by students as being particularly relevant. Following implementation of this seminar series, surveys assessing student attitudes towards the presented financial topics were distributed to all students on campus, and results were stratified by attendance and nonattendance at the seminars.

Results: Students who attended the seminars rated themselves as significantly more comfortable with all four financial topics (e.g. debt management, budgeting, investing, and retirement) compared to their peers who did not attend $(\mathrm{p}<0.05)$.

Conclusions: These findings demonstrate the efficacy of a small scale, student-run initiative to increase financial literacy on a single campus. Not only are these results a promising indication of the utility of a single club, they also offer a scaffold on which to build a formal personal and health care finance curriculum.

\section{Introduction}

Health professions students face unique financial challenges throughout their training, yet most receive minimal financial education prior to or during professional school. ${ }^{1}$ The increasing burden of student loan debt particularly affects the health professions, due to lengthy training and rising costs in education, ${ }^{2}$ with the average medical student graduating over $\$ 240,000$ in debt. ${ }^{3}$ The combination of high debt and lack of personal financial education makes these students especially vulnerable to the negative consequences of financial stress. Financial stress has been linked to higher rates of depression, anxiety, and burnout. ${ }^{4-6}$ To address this issue and explore how students at a Midwest public academic health sciences center perceive their own financial knowledge, students founded an organization in 2017 named the Financial Development Club (FDC). The primary mission of this organization is to empower all health professions students with knowledge that can help them take ownership over their personal finances, make informed early-career financial decisions, and improve well-being. To the knowledge of the authors, this is the first student-led interprofessional organization that provides personal financial education to students.

Because of the lack of data on personal financial education in professional schools, the researchers sought to discern if a seminar series, assembled by members of a student body, leads to gains in understanding of basic personal finance principles, and if heath professions students perceive that finance education seminars have a meaningful impact on their financial knowledge. Therefore, the aim of this study was to determine the efficacy of the newly formed FDC on the selfperceived financial knowledge and literacy of health professions students at an academic medical center.

\section{Methods}

Prior to the founding of the FDC (2017), health professions students at the University of Nebraska Medical Center (UNMC) were surveyed to identify gaps in their financial knowledge. The findings from this initial survey were used to inform the subsequent design and implementation of the seminar series and the creation of a formal research survey.

Throughout the 2017-2018 and 2018-2019 academic years, the FDC hosted quarterly evening programs concentrating on foundational personal finance topics. Local content experts were invited to share their specific financial knowledge in one-hour interactive seminars with students, comprised of 45-minutes of lecture and an interactive 15-minutes of question and answer with the option of submitting questions ahead of time to the speakers. The topics included debt managent, budgeting, investing, and retirement, and the speakers used a variety of techniques including powerpoints and worksheets to teach their individual topic. Health professions students on campus were invited to attend via email and attendance was voluntary.

To test the efficacy of the FDC, surveys were administered after each academic year (2017 - 2018 and 2018 - 2019). At the end of each academic year, all students were surveyed to assess their perceived confidence and knowledge of financial topics. Perceived confidence and knowledge were compared between students who attended and did not attend the seminar series. This study was IRB exempt (IRB \# 030-19-EX) by UNMC.

\section{Results}

Of the students surveyed prior to the founding of the FDC, $(\mathrm{N}=326), 92.3 \%$ had at least one area of concern regarding their financial future (Figure 1A) and 98.2\% believed they had room for growth in their knowledge and understanding of personal finance (Figure 1B). Additionally, fewer than one-in-five students believed their college provided adequate education on financial management (Figure 1C), and only $30 \%$ of students had a concrete plan to pay off their debt (Figure 1D). Students indicated specific interests in debt management, budgeting, investing, and retirement through a free response question in the survey (Figure 2).

Surveys assessing the necessity and efficacy of the FDC confirmed the vast majority of students $(87 \%)$ would like to know more about how to manage their personal finances before graduating. Additionally, $65 \%$ of students indicated a desire to have financial education formally-integrated into their professional school curriculum. Finally, students who attended the first two years of seminars rated themselves as significantly 
A.



Yes

No

c.

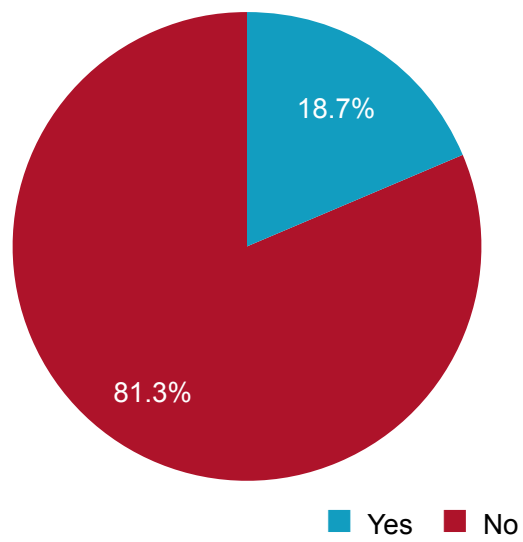

B.

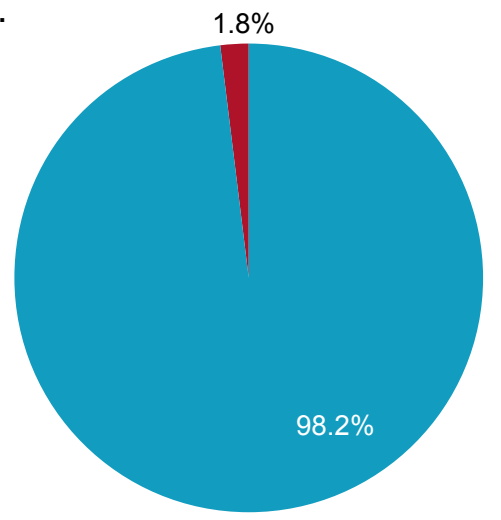

Yes

D.

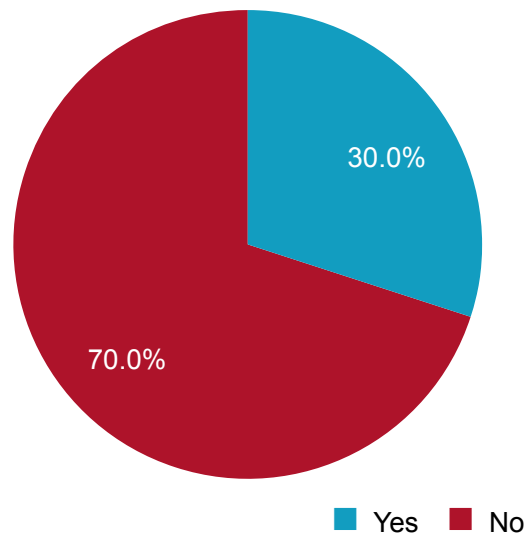

Figure 1. Preliminary Personal Finance Survey Results

A. Percentage of respondents who "have at least one area of concern regarding my financial future" [ $n=326]$.

B. Percentage of respondents who " believe there is room for growth in my knowledge and understanding of personal finance" $[n=326]$.
C. Percentage of respondents who believe their college "provides adequate education regarding financial management and development" [n=316].

D. Percentage of respondents who "have a concrete plan to pay off their debt" [ $n=323]$.

more comfortable with all four financial topics (e.g. debt management, budgeting, investing, and retirement) compared to their peers who did not attend $(\mathrm{p}<0.05)$ (Table 1$)$. Similarly, students who did not participate in seminars were significantly more likely to rate themselves as moderately or very uncomfortable with investing and retirement $(\mathrm{p}<0.05)$ (Table 2).

Every UNMC college was represented at the quarterly seminars. Seminar-attendees were comprised of the following: College of Medicine (38.2\%), College of Graduate Studies (18.0\%), College of Pharmacy (16.0\%), College of Allied Health (12.0\%) and All Others (15.8\%). All Others included the College of Nursing and the College of Public Health.

\section{Discussion}

A national survey of medical students $(\mathrm{N}=$ 4,604 ) highlighted a significant knowledge gap in financial literacy, with only $3 \%$ of students indicating that they felt very knowledgeable about their "understanding of personal financial issues," and only 5\% feeling very knowledgeable about their "understanding of student loan repayment options."7 These results are consistent with our survey of students prior to FDC seminars. Unfortunately, current medical students will face the highest burden of student debt in history: According to the National Center for Education Statistics, of medical students graduating with debt, the average amount is $\$ 240,000$, a $97 \%$ increase over the span of 17 years. ${ }^{8}$ Although 4 -in-10 students expect it will only take $6-10$ years to repay their student loans, the Association of American Medical Colleges (AAMC) repayment plans suggest it may take anywhere from $10-21$ years. ${ }^{9,10}$

\section{Graduation cost Money Ends Meet} Student Loans Interest Rates

\section{Pay off Loans House Investing scholarships Debt care $_{\text {Retirement }}$ Loan Repayment}

Figure 2. Financial topics of interest identified by students ${ }^{*}$

*The more often a specific word was mentioned, the larger it appears in the word cloud.

Authors at the Perelman School of Medicine at the University of Pennsylvania conducted an assessment of first- (M1) and fourthyear (M4) medical students across seven geographically distributed U.S. medical schools assessing performance on a financial literacy assessment. On average, students answered only $47 \%$ of financial literacy questions correctly. The results also showed a strong relationship between financial confidence and self-assessed financial knowledge. Additionally, students with higher financial literacy were more likely to have lower amounts of debt. Interestingly, students who had received school-provided personal financial counseling or information did not perform higher on the financial literacy questions, showing that there is room for 
improvement even in schools that do have financial education resources available for students. ${ }^{11}$

The FDC, a student-founded club at UNMC sought to tackle the gap in personal financial education for health professions students through the use of four, one-hour seminars taught by local content experts. In contrast to a formal curriculum, this seminar style program was developed due to its ease of implementation and voluntary nature. The seminars proved useful for those who attended compared to those who did not and may serve as a guide to the creation of a more formal curriculum. Although traditional professional education lacks formal opportunities in personal finance, there are examples of programs in professional schools that are attempting to tackle these issues. Fifteen graduate institutions have partnered with the Council of Graduate Schools to develop "GradSense," a financial education platform for students pursuing advanced degrees. In addition, they published a booklet for educators who want to create their own curricula. ${ }^{12}$ The American Physical Therapy Association has echoed the calls for financial education during professional school. As a result, they launched a "Financial Solutions Center," which offers physical therapy students a variety of online resources for a more personalized educational experience. ${ }^{13}$ Other professional training programs have attempted to provide similar resources for students. Financial aid departments and educators across the country have adopted a variety of approaches to tackle this deficiency, ranging from online resources to in-person workshops to four-year comprehensive curricula (Table 3).

The University of Missouri-Kansas Office of Student Affairs offers a variety of online resources for their students. Their website is categorized by topic, and includes budgeting, credit, debt management, insurance, investing, and more. ${ }^{15}$ Most of these resources are either from the AAMC, which has calculators, articles, and webinars available for students or Investopedia.com, a free online resource developed by editors, writers, product experts, developers, data scientists, analysts, and executives who are passionate about financial education and empowerment. ${ }^{16,17}$

Similar to the FDC's breadth of in-person topics, the Midwestern University College of Pharmacy designed a 10-week elective curriculum for second year students. The class met for 1.5 hours per week and covered a range of topics, including budgeting, analyzing credit, insurance, the principles
Table 1.

Self-rated confidence as "Moderately Comfortable" or "Very Comfortable"

\begin{tabular}{lccc} 
& Participants & Non-Participants & p value \\
\hline Debt Management & $74 \%(14)$ & $45 \%(83)$ & 0.017 \\
\hline Budgeting & $94 \%(17)$ & $63 \%(118)$ & 0.008 \\
\hline Investing & $72 \%(13)$ & $20 \%(38)$ & $<0.001$ \\
\hline Retirement & $56 \%(9)$ & $25 \%(47)$ & 0.007
\end{tabular}

Table 2.

Self-rated confidence as "Moderately Uncomfortable" or "Very Uncomfortable"

\begin{tabular}{lccc} 
& Participants & Non-Participants & p value \\
\hline Debt Management & $11 \%(2)$ & $31 \%(57)$ & 0.063 \\
\hline Budgeting & $6 \%(1)$ & $15 \%(27)$ & 0.291 \\
\hline Investing & $28 \%(5)$ & $61 \%(113)$ & 0.007 \\
\hline Retirement & $19 \%(3)$ & $52 \%(97)$ & 0.012
\end{tabular}

Table 3.

Selected Financial Programs in Professional Education*

\begin{tabular}{|c|c|c|c|c|}
\hline Program & Population & Format & Assessment & Other \\
\hline $\begin{array}{l}\text { University of } \\
\text { Missouri- } \\
\text { Kansas City }{ }^{15}\end{array}$ & $\begin{array}{l}\text { Medical } \\
\text { students }\end{array}$ & $\begin{array}{l}\text { Third party resources } \\
\text { for financial education } \\
\text { or one-on-one financial } \\
\text { counseling. }\end{array}$ & None & $\mathrm{N} / \mathrm{A}$ \\
\hline $\begin{array}{l}\text { University of } \\
\text { Nebraska Medical } \\
\text { Center Financial } \\
\text { Development Club }\end{array}$ & $\begin{array}{l}\text { Professional } \\
\text { students }\end{array}$ & $\begin{array}{l}4 \text { extra-curricular } \\
\text { seminars on debt } \\
\text { management, budgeting, } \\
\text { investing, and retirement }\end{array}$ & $\begin{array}{l}\text { Post-survey } \\
\text { comparing } \\
\text { confidence of } \\
\text { participants and } \\
\text { non-participants }\end{array}$ & $\mathrm{N} / \mathrm{A}$ \\
\hline
\end{tabular}

Midwestern Second-year Elective course: Abbreviated version Used certified

University ${ }^{18} \quad$ pharmacy $\quad 1.5$ hours per week for of Jump\$tart financial planners
students 10 weeks $\quad$ Financial Literacy for the first two Survey given years but the on first and last course coordinator day. Significant chose to provide all improvement (from lectures in the last $60-90 \%$ two years because of "sales pitches"

\begin{tabular}{|c|c|c|c|c|}
\hline $\begin{array}{l}\text { University of } \\
\text { Arkansas }^{14}\end{array}$ & $\begin{array}{l}\text { Fourth-year } \\
\text { medical } \\
\text { students }\end{array}$ & $\begin{array}{l}10 \text {-week elective with } \\
20 \text { hours of instruction, } \\
\text { including billing and } \\
\text { coding, taxes, investment } \\
\text { options, retirement } \\
\text { planning, starting a } \\
\text { practice, physician } \\
\text { recruitment, managing } \\
\text { personal cash flow, } \\
\text { contract negotiations, } \\
\text { and estate planning. }\end{array}$ & $\begin{array}{l}\text { Pre- and post- } \\
\text { assessments } \\
\text { gauging students' } \\
\text { interest, greatest } \\
\text { financial concerns, } \\
\text { and career goals. }\end{array}$ & $\begin{array}{l}\text { Incentive to } \\
\text { complete:graduate } \\
\text { with honors in } \\
\text { finance }\end{array}$ \\
\hline $\begin{array}{l}\text { Emory } \\
\text { University }{ }^{19-22}\end{array}$ & $\begin{array}{l}\text { Medical } \\
\text { students }\end{array}$ & $\begin{array}{l}\text { Debt management } \\
\text { and personal finance } \\
\text { workshops, classes, } \\
\text { and individual coaching } \\
\text { sessions }\end{array}$ & $\begin{array}{l}\text { Senior capstone } \\
\text { pilot program } \\
\text { assessed }\end{array}$ & N/A \\
\hline
\end{tabular}

$\begin{array}{llll}\text { University of } & \text { Medical } & \text { Online survey is } & \text { Financial aid office }\end{array}$

California Irvine $23,24 \quad$ students forgiveness, transitioning students' debt third-party company from medical school to awareness to provide their residency, the cost of and financial workshops applying for a medical literacy and tailor residency, how to presentations for manage student loans the upcoming year. during residency, repayment strategies

*This is not intended to be a complete list. 
of investing, preparing income taxes, and how to facilitate discussions with financial professionals. Pre- and post-assessments from the Jump\$tart Financial Literacy Survey were administered. The mean baseline score was $60 \%$, which improved to $89.9 \%(\mathrm{p}<0.001)$ after 10 weeks. Students also rated the course very highly indicating that it "was useful in preparing them to become pharmacists." 18

The University of Arkansas for Medical Sciences (UAMS) created a fourth-year elective for medical students. Prior to the course, students completed a 45-question survey about their interest, knowledge, financial status, and career goals. They then attended 20 hours of lectures over a 10-week period on topics ranging from billing and coding to income taxes to estate planning. At the conclusion, students took a post-survey on the topics that were covered to see if interest or behavioral changes occurred. Similar to the UNMC FDC survey, UAMS students also experienced increased feelings of competence in managing current or future personal finances as well as their ability to manage debt. In addition, students felt strongly that business aspect of medicine should be taught in medical school. Similarly at UNMC, nearly two-thirds of respondants indicated a desire to have financial education formally-integrated into their professional school curriculum. In addition, behavioral changes occurred, with $95 \%$ of students saying that they had made some type of change, including budgeting, starting a retirement plan, changing spending habits, and more. The curriculum is continuing to be optimized, as certain topics with less interest have been replaced, while others have been added or expanded. At this time, it is now the highest attended elective on the UAMS campus. The formal integration of personal finance into UAMS's curriculum may serve as an example for schools whose current financial workshops are extracurricular.

Emory University School of Medicine offers workshops, classes, and individual coaching sessions as part of their "Debt Management Initiative." 19 This four-year program is intended to provide financial security to students by providing resources to manage their finances during school and following graduation. They also provide online resources through their financial services office, the Department of Education, and the AAMC. ${ }^{20,21}$ Additionally, the associate director of financial aid and scholarships piloted a 3.5-hour personal finance workshop during the senior year capstone. A survery was distributed to assess the benefit of this workshop. Of the 117 student respondents,
$79 \%$ noted they would develop a personal strategy for saving, $71 \%$ said they would employ strategies to improve and protect their credit/identity, and $64 \%$ felt the workshop provided them with tools that would be useful in their practice of medicine..$^{22}$ In comparison Emory's senior workshop, participants at FDC's seminars also experienced improvements in knowledge. Similar to UAMS, Emory attempted to assess behavioral changes. This may be an important outcome measure for personal finance curricula that are meant to improve financial decision-making.

The University of California-Irvine (UCI)

Financial Aid office has designed an innovative curriculum of presentations and resources for medical students from the time of admission until graduation. Students are given 10 or more in-person presentations by financial aid office staff or experts in the field. These presentations are tailored to the specific needs of students depending on their year in the program. For example, second-year medical students learn about the costs of preparing, registering, and studying for USMLE Step 1, while fourthyear medical students learn about budgeting for residency interviews. In addition, they have partnered with CashCourse, a free online financial education resource funded by the National Endowment for Financial Education, to provide comprehensive resources to students. ${ }^{23}$ Online workshops on debt management and financial literacy as well as other quizzes, calculators, and self-study tools are available at the students' convenience. Surveys are done annually to optimize the content for future classes. ${ }^{24}$ From the perspective of the authors, this curriculum is the most comprehensive and best designed to meet the students' needs, both because it spans all four years of medical school and also provides information that is time-specific during training.

Medical students with more debt are more likely to choose a specialty with a higher average annual income, are less likely to plan to practice in underserved locations, and are less likely to choose primary care specialties. ${ }^{6,25}$ Therefore, the implementation of a financial education course during medical school, may lead to improvement in knowledge leading to greater early-career financial decision making and increased confidence resulting in a stronger commitment to primary care and caring for underserved populations.

The needs for financial literacy education should not stop at the conclusion of medical school. Many studies show that residents and fellows have high interest in financial education and have varying levels of financial literacy, with some studies noting a low level of competence in several aspects of personal finance. ${ }^{26-28}$ In a 2017 survey of 1,573 resident physicians aged between $25-29$ years of age over $70 \%$ had medical school debt with $50 \%$ of them having over $\$ 200,000$ in debt. Their primary financial worry was an inability to pay off their debt. Two-thirds of respondents also reported consumer debt such as credit cards, car loans, and mortgages. Approximately $78 \%$ of respondents had less than $\$ 25,000$ in retirement savings and over $60 \%$ of the overall respondents felt behind in saving for retirement. Therefore, financial education may be even more critical for residents due to the evolving financial landscape and changes in professional and personal commitments during residency.

Limitations. While student perception and confidence are important, a major limitation of our work thus far has been the lack of objective assesement of the benefits of the FDC. Future directions for the FDC will include modifications and validation of the survey tool used, to include objective competency measures.

Future Directions. Ideally, students would enter professional school with financial knowledge from undergraduate education or work experience. However, because of the rigorous pre-requisite coursework required, most health professions students do not have the time nor knowledge needed to manage their personal finances. Due to the diverse needs of students throughout various timepoints in undergraduate and graduate medical education, one potential solution could be a collaboration to develop a rigorous, long-term approach for money management. Like UAMS, Emory, and UCI, financial aid offices could continue to teach students about the basics of debt management, loan repayment programs, investing, costs of medical education, and buying a home. If students, upon graduation, enter into a residency or other further formalized training programs, there is the opportunity for these programs to pick up where the others left off, providing education on filing taxes, insurance, coding and billing, establishing private practices, and contract negotiation. This longterm approach will ensure pertinent topics are covered at the appropriate time points, and it will put students in the best position to repay their debt, invest wisely, and and maintain financial stability. However, if students, upon graduation, enter into their career, it is much more likely that further education will need to be self-driven thus making finding good 
quality, readily-available financial education resources a high priority.

\section{Conclusions}

In conclusion, the Financial Development Club (FDC) was founded to address the increasing financial stresses health professions students experience by providing the financial education currently missing in most professional school curricula. Our results demonstrate the positive impact financial education can have on improving fiscal literacy for health profressions students. While we feel the student-led nature of our group has been a strength, integration into the formal medical curriculum will be key for long-term success. Our efforts could therefore serve as an innovative example of students directly impacting their own education by prototyping new curricula elements prior to formal integration.

https://doi.org/10.32873/unmc.dc.gmerj.2.2.003

\section{Acknowledgments}

The authors would like to thank all our faculty sponsors and invited speakers who generously volunteered their time and knowledge.

\section{Conflict of Interest}

The authors declare no conflict of interest.

\section{References}

1 Dhaliwal G, Chou CL. A Brief Educational Intervention in Personal Finance for Medical Residents. J Gen Intern Med. 2007;22(3):374-377.

2 Steinbrook R. Medical Student Debt - Is There a Limit? N Engl J Med. 2008;359(25):2629-2632.

3 "Digest of Education Statistics, 2018." Percentage of Graduate Degree Completers with Student Loan Debt and Average Cumulative Amount Owed, by Level of Education Funded and Graduate Degree Type, Institution Control, and Degree Program: Selected Years, 1999-2000 through 2015-16, The National Center of Education Statistics , Jan. 2018, nces.ed.gov/ programs/digest/d18/tables/dt18_332.45.asp.

4 Connelly, Peter, and Cassandra List. "The Effect of Understanding Issues of Personal Finance on the Well-being of Physicians in Training." WMJ : official publication of the State Medical Society of Wisconsin vol. 117,4 (2018): 164-166.

5 Royce, Trevor J et al. "A Burnout Reduction and Wellness Strategy: Personal Financial Health for the Medical Trainee and Early Career Radiation Oncologist." Practical radiation oncology vol. 9,4 (2019): 231-238. doi:10.1016/j.prro.2019.02.015

6 Pisaniello, Monique Simone et al. "Effect of medical student debt on mental health, academic performance and specialty choice: a systematic review." $B M J$ open vol. 9,7 e029980. 2 Jul. 2019, doi:10.1136/ bmjopen-2019-029980

7 AMA Insurance Agency, Inc. "2017 Report on U.S. Physicians' Financial Preparedness." AMA Insurance, 2017, www.amainsure.com/research-reports/2017 financial-preparedness-medical-students/index. html?page $=1$.

8 "Digest of Education Statistics, 2018." Percentage of Graduate Degree Completers with Student Loan Debt and Average Cumulative Amount Owed, by Level of Education Funded and Graduate Degree Type, Institution Control, and Degree Program: Selected Years, 1999-2000 through 2015-16, The National Center of Education Statistics , Jan. 2018, nces.ed.gov/ programs/digest/d18/tables/dt18 332.45.asp.

9 AMA Insurance Agency, Inc. "2017 Report on U.S. Physicians' Financial Preparedness." AMA Insurance, 2017, www.amainsure.com/research-reports/2017financial-preparedness-medical-students/index. html?page $=1$.

10 AAMC. "2018 Education Debt Manager For Graduating Medical School Students." Financial Information, Resources, Services, and Tools (FIRST), Association of American Medical Colleges, Jan. 2018, medschool.ucsd.edu/admissions/financialaid/Documents/2018\%20Education $\% 20$ Debt $\% 20$ Manager\%20for\%20Graduating\%20Students.pdf.

11 Jayakumar, Kishore L., et al. "Personal Financial Literacy Among U.S. Medical Students." MedEdPublish, vol. 6, no. 1, 21 Feb. 2017 doi:10.15694/mep.2017.000035.

12 "Enhancing Student Financial Education." Professional Development for Graduate Students, Council of Graduate Schools, 2020, cgsnet.org/ enhancing-student-financial-education.

13 Koria, Keith. Financial Literacy and the New DPT Grad. American Physical Therapy Association, 1 Feb. 2017, www.apta.org/apta-magazine/2017/02/01/ financial-literacy-and-the-new-dpt-grad.

14 Mizell, Jason S., et al. "The Business of Medicine: A Course to Address the Deficit in Financial Knowledge of Fourth-Year Medical Students." American Association for Physician Leadership, 28 Jan. 2020, www.physicianleaders.org/news/the-business-ofmedicine-a-course-to-address-the-deficit-in-financialknowledge-of-fourth-year-medical-students.

15 University of Missouri Kansas City School of Medicine. "Office of Student Affairs Financial Literacy." UMKC School of Medicine, 2020, med. umkc.edu/sa/finance/.
16 Association of American Medical Colleges Financial Information, Resources, Services, and Tools. "Financial Aid." AAMC For Students, Applicants and Residents, 2020, students-residents.aamc.org/ financial-aid/.

17 Investopedia. "Who We Are." Investopedia, DotDash, www.investopedia.com/about-us\#WhoWeAre.

18 Chui, Michelle A. "An elective course in personal finance for health care professionals." American journal of pharmaceutical education vol. 73,1 (2009): 6. doi:10.5688/aj730106

19 Emory University School of Medicine. "Financial Aid Resources and Helpful Links." Financial Aid Resources and Helpful Links | Emory School of Medicine, 2018, med.emory.edu/education/programs/ $\mathrm{md} /$ student-handbook/costs-financial-aid/resources. html.

20 Emory University School of Medicine. "Wellness and Well-Being." Wellness and Well-Being | Emory School of Medicine, 2018, med.emory.edu/education/ programs/md/student-handbook/student-resources/ wellness.html.

21 Emory University School of Medicine "Doctor of Medicine Student Handbook 2019-2020 .” Doctor of Medicine Student Handbook 2019-2020 Emory University School of Medicine, 2019, med.emory.edu/ education/programs/md/student-handbook/.

22 Liebzeit, Jason, et al. "Financial Literacy for the Graduating Medical Student." Medical Education, vol. 45, no. 11, 2011, pp. 1145-1146., doi:10.1111/j.13652923.2011.04131.x.

23 Conrad, Amy Marty, et al. "About." CashCourse Your Real-Life Money Guide, National Endowment For Financial Education, 2020, www.cashcourse.org/info/ About.

24 University of California Irvine Financial Aid and Scholarships. "Debt Management and Financial Literacy." Debt Management and Financial Literacy: Medical Students, 10 Dec. 2019, www.ofas.uci.edu/ content/SOMDebtManagement.aspx?nav=19.

25 Fong, Jie Ming Nigel et al. "Impact of financial background and student debt on postgraduate residency choices of medical students in Singapore." Singapore medical journal vol. 59,12 (2018): 647-651. doi:10.11622/smedj.2018068

26 Shappell, Eric, et al. "Personal Finance Education for Residents: A Qualitative Study of Resident Perspectives." AEM Education and Training, vol. 2, no. 3, 2018, pp. 195-203., doi:10.1002/aet2.10090.

27 Mckillip, Ryan, et al. "Toward a Resident Personal Finance Curriculum: Quantifying Resident Financial Circumstances, Needs, and Interests." Cureus, 2018 , doi: $10.7759 /$ cureus.2540.

28 Bar-Or, Yuval D, et al. "Implementation of a Comprehensive Curriculum in Personal Finance for Medical Fellows." Cureus, 2018, doi:10.7759 cureus.2013 